\title{
Prenatal Diagnosis dan Penatalaksanaan Gastroskisis
}

\author{
William Alexander Setiawan \\ Fakultas Kedokteran Universitas Kristen Krida Wacana \\ Korespondensi: William Alexander Setiawan, Email: William.alexanders11@gmail.com
}

\begin{abstract}
Abstrak
Gastroskisis merupakan defek kongenital yang terjadi pada dinding abdomen janin. Kejadian yang dilaporkan di seluruh dunia berkisar antara 4-5 per 10.000 kelahiran hidup. Mortalitas pada bayi yang lahir dengan Gastroskisis telah menurun selama bertahun-tahun tetapi morbiditas masih tetap tinggi. Diperlukan prenatal diagnosis yang optimal agar proses melahirkan bisa dipersiapkan sebaik mungkin. Pada prenatal diagnosis dilakukan penilaian defek kongenital lainnya agar hasil klinis lebih baik dengan manajemen lebih awal, selain itu dilakukan juga penilaian untuk menentukan adanya kelainan kromosom atau tidak. Apabila kelainan tersebut bersifat isolated, maka hasil klinis akan lebih baik dibandingkan Gastroskisis dengan kelainan kromosom. Metode persalinan dan waktu persalinan yang direkomendasikan yaitu pada usia kehamilan 37 minggu dengan metode sectio caesarea. Manajemen neonatal meliputi persalinan di fasilitas kesehatan tersier dan manajemen bedah paska kelahiran yaitu penutupan bedah primer, penutupan bertahap dengan silo, atau penutupan umbilikal tanpa jahitan.
\end{abstract}

Kata kunci: Defek Kongenital, Gastroskisis, Prenatal Diagnosis

\section{Prenatal Diagnosis and Management of Gastroschisis}

\begin{abstract}
Gastroskisis is a congenital defect that occurs in the fetal abdominal wall. Events reported throughout the world range from 4-5 per 10,000 live births. Mortality in infants born with Gastroskisis has declined over the years but morbidity is still high. An optimal prenatal diagnosis is needed so that the labor can be prepared as well as possible. Prenatal diagnosis is done by assessing other congenital defects so that clinical results are better with earlier management, in addition assessment is also done to determine whether there is a chromosome abnormality or not. If the abnormality is isolated, the clinical results will be better than Gastroskisis with chromosomal abnormalities. The recommended method of delivery and labor time is 37 weeks gestational age with the sectio caesarea method. Neonatal management includes delivery in tertiary health facilities and management of postnatal surgery namely primary surgical closure, staged reduction with silo and sutureless umbilical closure.
\end{abstract}

Key words: Congenital Defect, Gastroskisis, Prenatal Diagnosis 


\section{Latar Belakang}

Gastroskhisis merupakan defek kongenital yang terjadi pada dinding abdomen janin.

Pada Gastroskisis, visera dinding abdomen tidak tertutup sehingga usus, lambung dan terkadang organ perut lainnya seperti ovarium, kandung kemih dan hati keluar melalui defek tersebut. Pada keadaan normal, ketika usia kehamilan 6 minggu, usus bayi berada di luar abdomen, dan ketika usia kehamilan mencapai 10 minggu usus akan masuk ke dalam abdomen dan dinding abdomen menutup. ${ }^{1}$

Etiologi Gastroskisis adalah gangguan yang terjadi pada arteri omfal kanan, yang menyebabkan terjadinya iskemik pada dinding perut anterior, sehingga struktur perut tersebut mengalami herniasi yang dapat mengakibatkan pecahnya dinding perut anterior. Oleh karena itu, karakteristik dari penyakit ini adalah adanya organ perut janin yang keluar mengambang di cairan ketuban. ${ }^{2}$

Kejadian gastoschisis di dunia berkisar antara 4-5 per 10.000 kelahiran hidup dan lebih sering terjadi pada bayi prematur, bayi berat lahir rendah dan bayi perempuan. Pada kasus yang sangat langka, dapat terjadi defek dinding abdomen yang menutup sempurna di sekitar daerah eviserasi sehingga mengakibatkan Gastroskisis tertutup, namun angka kejadian hanya $6 \%$ dari semua kasus Gastroskisis. Di Indonesia belum jelas angka kejadian Gastroskisis namun Indonesia merupakan negara dengan risiko tinggi karena terdapat faktor risiko penyebab Gastroskisis yaitu kehamilan pada usia muda, paritas tinggi dan kekurangan asupan gizi pada ibu hamil. ${ }^{3}$ Penelitian yang dilakukan Nukana pada tahun 2012 mengemukakan kejadian Gastroskisis di RSUP Sanglah pada tahun 2010-2012 mencapai 37 kejadian. ${ }^{4}$ Dahulu, mortalitas Gastroskisis sekitar 30\%, namun beberapa tahun terakhir berangsur menurun hingga kini mencapai 5\%. Mortalitas berhubungan dengan berbagai faktor seperti komplikasi yang muncul sebelum dan setelah operasi. Angka mortalitas juga dapat menunjukkan tingkat keberhasilan suatu penanganan. ${ }^{5}$

Penanganan utama Gastroskisis adalah dengan operasi. Prinsip operatif Gastroskisis yaitu mengembalikan organ yang keluar ke dalam abdomen dan menutup defek pada dinding abdomen tersebut. Teknik bedah dari Gastroskisis dibedakan menjadi tiga yaitu teknik penutupan primer, penutupan bertahap dan penutupan tanpa jahitan. Masing-masing teknik memiliki indikasi sesuai dengan kondisi masing-masing pasien. ${ }^{6}$

Penulis tertarik untuk membuat tulisan ini dikarenakan kejadian Gastroskisis cukup sering ditemui. Morbiditas Gastroskisis masih cukup tinggi walau mortalitasnya kini bisa ditekan dengan perkembangan teknik operasi pada Gastroskisis.

\section{Prenatal diagnosis}

Bila kita dapatkan adanya defek pada dinding abdomen melalui USG, Gastroskisis dan omfalokel merupakan 2 etiologi tersering. perbedaan omfalokel dengan Gastroskisis yaitu adanya herniasi organ-organ internal, organ-organ tersebut tertutup kantung yang terbuat dari 3 lapisan peritoneum.

Perbedaan-perbedaan lainnya antara Gastroskisis dan omfalokel dijelaskan dalam Tabel 1. Diagnosis banding lainnya pada defek dinding abdomen antara lain cloacal exstrophy, ektopia cordis, ruptur omfalokel, hernia tali pusat, limb-body wall complex, kista urachal. Namun diagnosis biasanya dapat ditegakkan dengan pemeriksaan USG.

Diagnosis Gastroskisis sering disertai dengan peningkatan maternal serum $\alpha$-fetoprotein (msAFP). Peningkatan kadar $\alpha$-fetoprotein terjadi akibat distribusi dari janin ke cairan amnion melalui defek pada dinding abdomen. Dalam keadaan normal, kadar MsAFP berkisar antara 3,5-13,5 ng/ $\mathrm{mL}$. Namun, dengan kemajuan teknologi pada USG, diagnosis bisa ditegakkan dengan 
Tabel 1 Perbandingan Gastroskisis dan Omfalokel ${ }^{6}$

\begin{tabular}{|c|c|c|}
\hline & Gastroskisis & Omfalokel \\
\hline Definisi & $\begin{array}{l}\text { gastro: perut, schisis: celah } \\
\text { Defek dinding abdomen pada sisi kanan um- } \\
\text { bilikus disertai organ-organ abdomen yang } \\
\text { keluar tanpa penutup membrane. }\end{array}$ & $\begin{array}{l}\text { omfalos: umbilikus, cele: hernia } \\
\text { Herniasi organ-organ abdomen melalui defek } \\
\text { umbilical, terdiri dari } 3 \text { lapisan membrane. }\end{array}$ \\
\hline Insiden & 4-5 per 10.000 kehamilan & 4 per 10.000 kehamilan \\
\hline Patogenesis & $\begin{array}{l}\text { Kegagalan mesoderm dalam membentuk dind- } \\
\text { ing perut, ruptur amnion di sekitar cincin um- } \\
\text { bilikus, involusi abnormal pada vena umbilical } \\
\text { kanan yang menyebabkan melemahnya dinding } \\
\text { abdomen, gangguan pada arteri vitelline kanan } \\
\text { atau arteri yolk sak yang kemudian menyebab- } \\
\text { kan kerusakan pada dinding abdomen }\end{array}$ & $\begin{array}{l}\text { Kegagalan organ-organ abdomen untuk kem- } \\
\text { bali ke rongga abdomen setelah terjadinya } \\
\text { herniasi tali pusat pada usia kehamilan } 6-10 \\
\text { minggu }\end{array}$ \\
\hline USG & $\begin{array}{l}\text { Defek sering ditemukan di bagian kanan tali } \\
\text { pusat, terdapat herniasi organ-organ abdomen } \\
\text { tanpa membran yang menutupinya }\end{array}$ & $\begin{array}{l}\text { Defek terletak di sentral, terdapat herniasi } \\
\text { organ-organ abdomen disertai membran yang } \\
\text { menutupinya. Jika membran pembungkusnya } \\
\text { mengalami ruptur, gambaran akan menyeru- } \\
\text { pai Gastroskisis namun disertai kelainan tali } \\
\text { pusat dan sisa kantung omfalokel. }\end{array}$ \\
\hline $\begin{array}{l}\text { Kelainan } \\
\text { Genetik }\end{array}$ & $0,1 \%$ disertai kariotipe yang abnormal & $30-40 \%$ disertai kariotipe yang abnormal \\
\hline
\end{tabular}
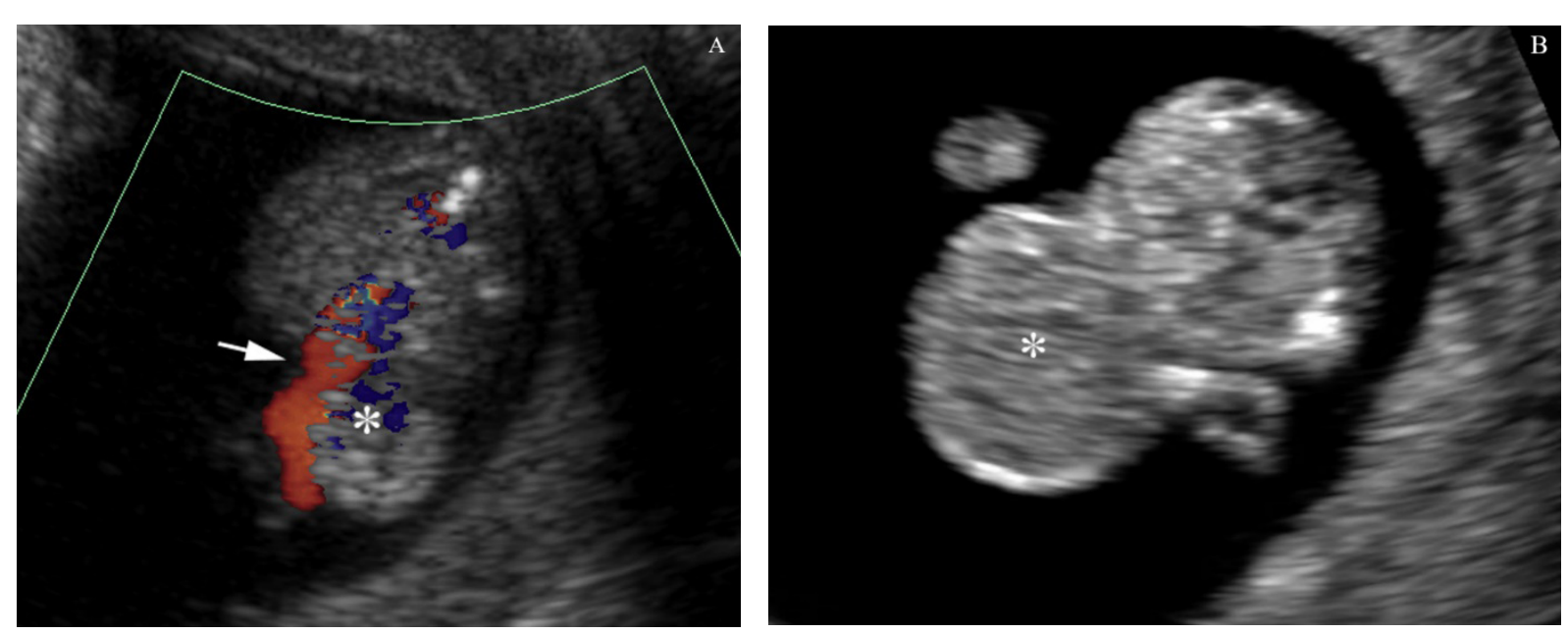

Gambar 1. (a) Gambaran tranversal pada abdomen janin usia 12 minggu, menunjukkan Gastroskisis: herniasi usus (*) terlihat di sisi lateral dari insersi tali pusat. (b) Gambaran transversal pada abdomen janin usia 12 minggu, menunjukkan omfalokel yang besar. ${ }^{7}$ 


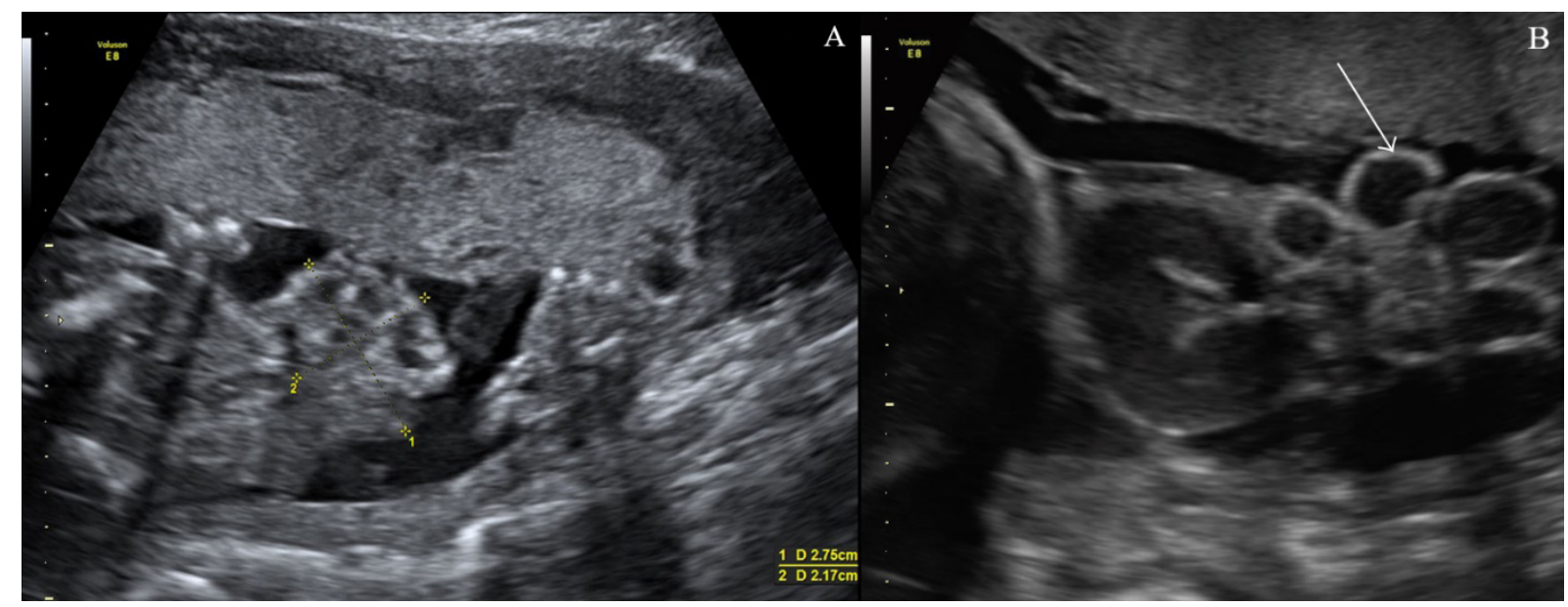

Gambar 2 Tampak bagian usus melayang bebas di cairan ketuban. (a) Gambaran USG janin dengan Gastroskisis pada usia kehamilan 25 minggu. ${ }^{8}$ (b) Gambaran USG janin dengan Gastroskisis pada usia kehamilan 31 minggu. ${ }^{9}$
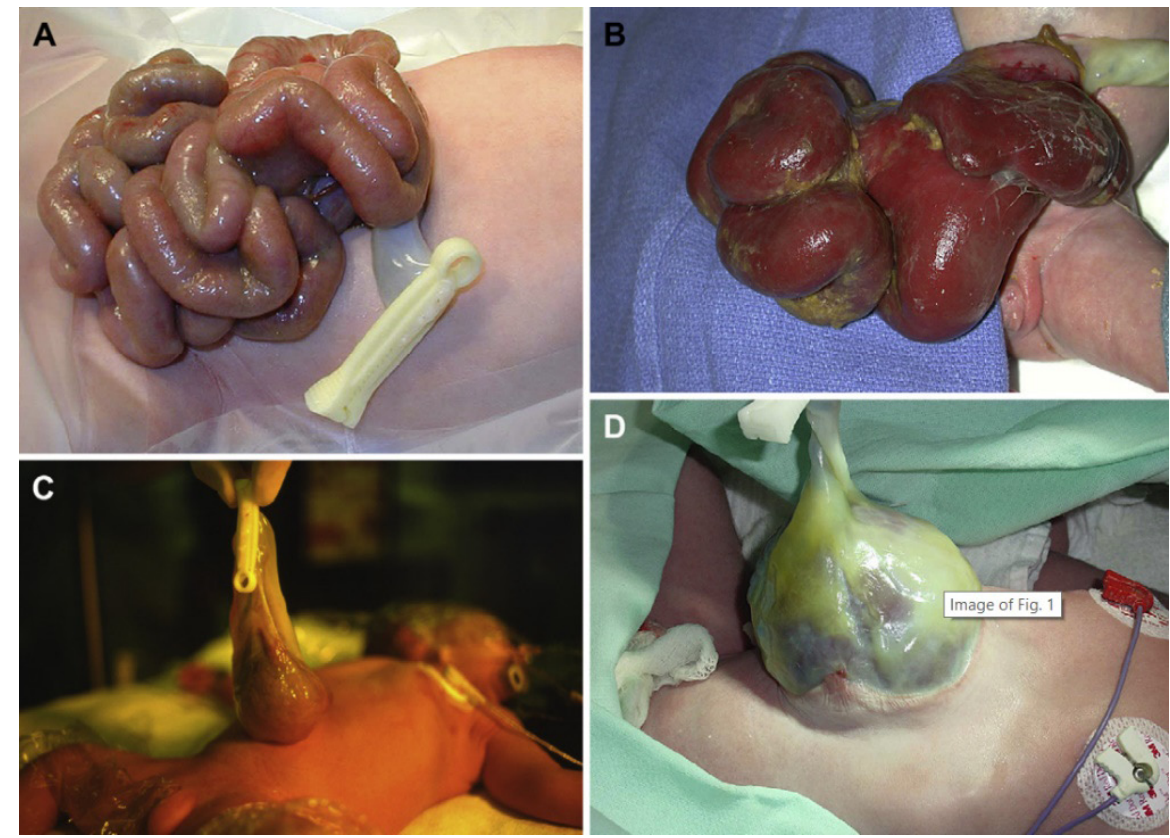

Gambar 3 Gambaran Gastroskisis dan omfalokel. (a) Gastroskisis dengan usus normal. (b) Gastroskisis dengan kerusakan signifikan pada usus, tampak perlengketan, pengelupasan dan pemendekan. (c) Omfalokel kecil. (d) Omfalokel besar disertai hepar. ${ }^{10}$

USG.

Pada pemeriksaan USG akan tampak gambaran defek pada dinding perut paraumbilikalis dengan organ abdomen yang menonjol keluar melalui defek tersebut. Defek ini biasanya berada di sebelah kanan garis tengah. Perut dapat melebar atau mengalami herniasi melalui defek dinding abdomen. ${ }^{10}$ Organ abdomen yang mengalami herniasi tidak memiliki membran penutup, sehingga akan tampak organ abdomen yang mengapung bebas di cairan amnion. Di akhir kehamilan, gambaran USG akan menunjukkan dinding usus yang menebal akibat paparan kronis terhadap cairan amnion. Gambaran lain yang mungkin terjadi yaitu terjadinya pelebaran usus intraabdomen atau dilatasi usus ekstra-abdomen. Jika didapatkan gambaran polihidramnion yang berhubungan dengan pelebaran usus, kemungkinan hal ini 


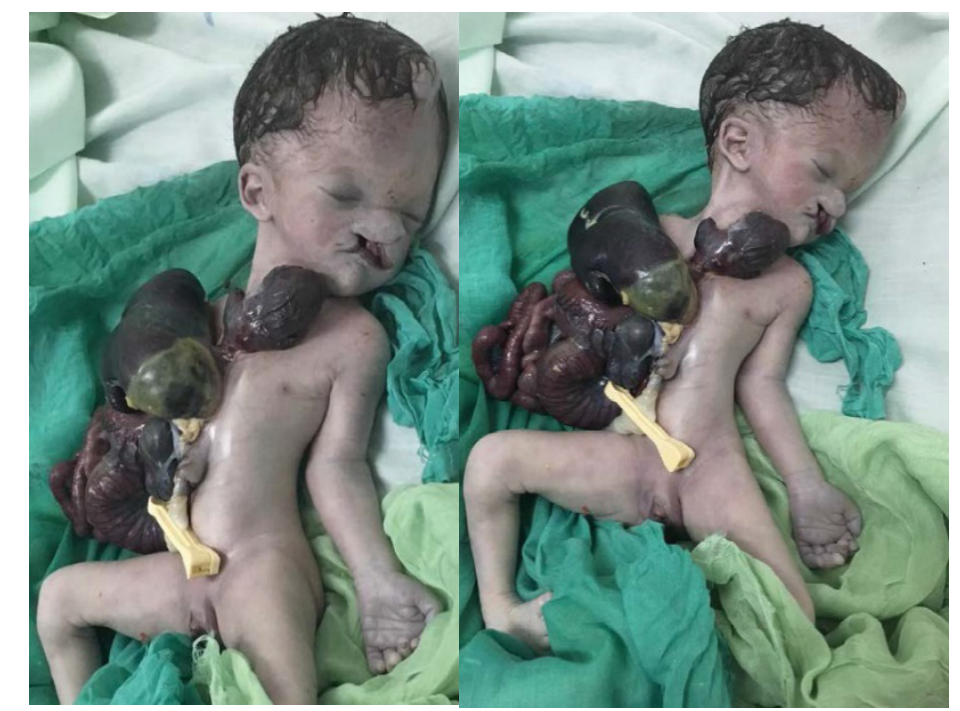

Gambar 4 Bayi lahir dengan beberapa anomali kongenital, labiopalatoschisis, equino varus, Gastroskisis dengan eviserasi hepar, usus halus, usus besar, jantung. ${ }^{2}$

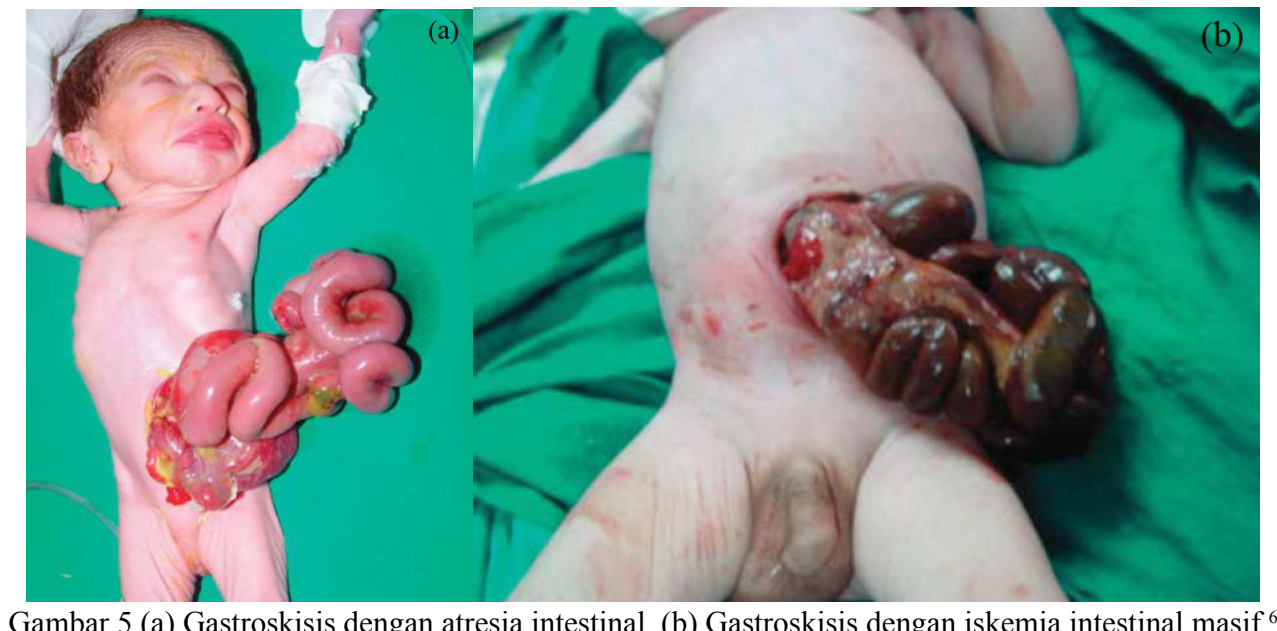

mengarah pada atresia usus. ${ }^{11}$ Kelainan kromosom jarang terjadi pada Gastroskisis. Kejadian Gastroskisis yang disertai kelainan kromosom hanya $0,1 \%$ dari semua kejadian Gastroskisis. Oleh karena itu, tanpa kelainan struktural non-gastrointestinal, evaluasi genetik janin tidak perlu dilakukan. ${ }^{12}$

\section{Penanganan Antenatal}

Ultrasonografi janin membawa manfaat signifikan untuk diagnosis. Hasil USG yang valid bisa didapatkan setelah usia kehamilan 14 minggu. Gambaran USG pada Gastroskisis akan menunjukkan defek kecil pada dinding perut bagian anterior yang terletak di sisi lateral kanan umbilikus dan organ abdomen keluar melalui defek tersebut menuju cairan amnion. Coloured Doppler Ultrasound dapat digunakan untuk mendeteksi kelainan pada tali pusat.m. Setelah prenatal diagnosis dibuat, akan dilakukan diskusi untuk penanganan selanjutnya oleh dokter kandungan, dokter anak dan dokter bedah anak. Kontrol USG dilakukan setiap dua bulan untuk monitoring dalam memprediksi komplikasi. Beberapa penelitian di negara-negara maju menjelaskan bahwa tidak ada hubungan yang bermakna antara prenatal diagnosis terhadap outcome bayi dengan Gastroskisis. 
Beberapa penelitian juga menunjukkan bahwa operasi sectio caesarea pada usia kehamilan 36-37 minggu dapat mengurangi morbiditas dibandingkan dengan persalinan pervaginam karena risiko infeksi atau perforasi visera. ${ }^{13}$

Pada kasus Gastroskisis, sering terjadi compromise pada usus. Hal ini terjadi akibat pajanan usus yang lama dengan cairan amnion. Kompresi pada usus dan pembuluh darah di daerah sekitar defek juga sering ditemukan. Terdapat beberapa penelitian yang mempelajari tentang pertukaran cairan amnion dengan saline, namun hal tersebut tidak meningkatkan hasil. Pada saat ini, tidak ada terapi uterofetal yang terbukti membawa manfaat signifikan pada kejadian Gastroskisis.

\section{Proses Persalinan}

Persalinan direkomendasikan untuk dilakukan di fasilitas kesehatan tersier dimana unit perawatan intensif neonatal dan tim bedah anak tersedia. Persalinan yang dilakukan di luar fasilitas kesehatan tersier akan berisiko meningkatkan komplikasi pada bayi yang lahir dengan Gastroskisis. Terdapat beberapa teori mengenai persalinan prematur elektif sehingga paparan usus terhadap cairan amnion menurun dan akan meminimalkan nekrosis, atresia, atau nekrotikan enterokolitis. Namun, persalinan prematur elektif juga akan meningkatkan risiko komplikasi sindrom gangguan pernapasan, yang akan mempersulit persiapan pembedahan. ${ }^{14}$

Beberapa penelitian mengenai waktu persalinan yang optimal berbeda-beda. Mesas et al menjelaskan bahwa waktu persalinan terbaik berkisar antara $35-<37$ minggu dan merekomendasikan persalinan dengan sectio caesarea. $^{15}$ Baud et al menjelaskan bahwa induksi persalinan pada usia kehamilan 37 minggu berhubungan dengan penurunan risiko sepsis, kerusakan usus, dan kematian neonatal. ${ }^{16}$ Carnaghan et al menjelaskan bahwa persalinan sebelum 37 minggu berhubungan dengan peningkatan durasi lama rawat inap di rumah sakit. ${ }^{17}$ Cain et al menemukan bahwa persalinan pada usia kehamilan diatas 37 berhubungan dengan peningkatan outcome perinatal bila dibandingkan dengan persalinan sebelum 37 minggu. ${ }^{18}$ Youssef et al menjelaskan bahwa untuk setiap minggu dalam kandungan, persentase janin dengan gangguan kontur dinding usus halus berkurang sebesar 3,6\%. ${ }^{19}$ Hal ini bertentangan dengan beberapa penelitian yang menjelaskan bahwa terminasi kehamilan dilakukan untuk mengurangi paparan usus ke cairan amnion. Sebaliknya, Nasr et al menjelaskan bahwa persalinan setelah 38 minggu berhubungan dengan peningkatan penebalan usus. ${ }^{20}$ Berdasarkan penelitian yang ada, kami umumnya merekomendasikan persalinan pada usia kehamilan 37 minggu.

Terdapat beberapa penelitian yang saling bertentangan mengenai metode persalinan yang optimal untuk menangani Gastroskisis. Beberapa peneliti merekomendasikan persalinan dengan sectio caesarea karena memberikan hasil yang lebih baik. ${ }^{15}$ Namun terdapat penelitian yang menunjukan hasil bahwa persalinan normal tidak berkaitan dengan outcome yang buruk. ${ }^{21}$ Kami merekomendasikan persalinan dengan metode sectio caesarea.

Pada saat persalinan, tim perawatan intensif neonatal harus hadir. Setelah bayi lahir, organ abdomen yang keluar harus dibalut dengan kain salin steril untuk meminimalisasi kehilangan cairan pada bayi. Perawatan paska kelahiran mencakup pemasangan tabung orogastrik untuk dekompresi lambung dan pemasangan jalur intravena untuk memberikan cairan dan antibiotik. Dalam 24 jam pertama, cairan yang hilang dapat mencapai 2,5 kali lipat dibandingkan dengan bayi baru lahir yang sehat. Hal ini dikarenakan panas berlebih dan kehilangan cairan akibat pajanan bakteri 
pada organ abdomen yang keluar. Beberapa bentuk intervensi bedah harus dilakukan segera untuk mengurangi kerugian ini.

\section{Penanganan Bayi Baru Lahir}

Terdapat 3 kategori manajemen bedah dalam menangani Gastroskisis yaitu (1) penutupan fasia primer, (2) penempatan silo dengan penutupan bertahap, dan (3) penutupan umbilical tanpa jahitan. Penutupan fasia primer merupakan metode penutupan yang dominan digunakan sekitar tahun 1990-an. Munculnya Silastic Silo menggeser dominasi teknik penutupan primer. Meta-analisis yang
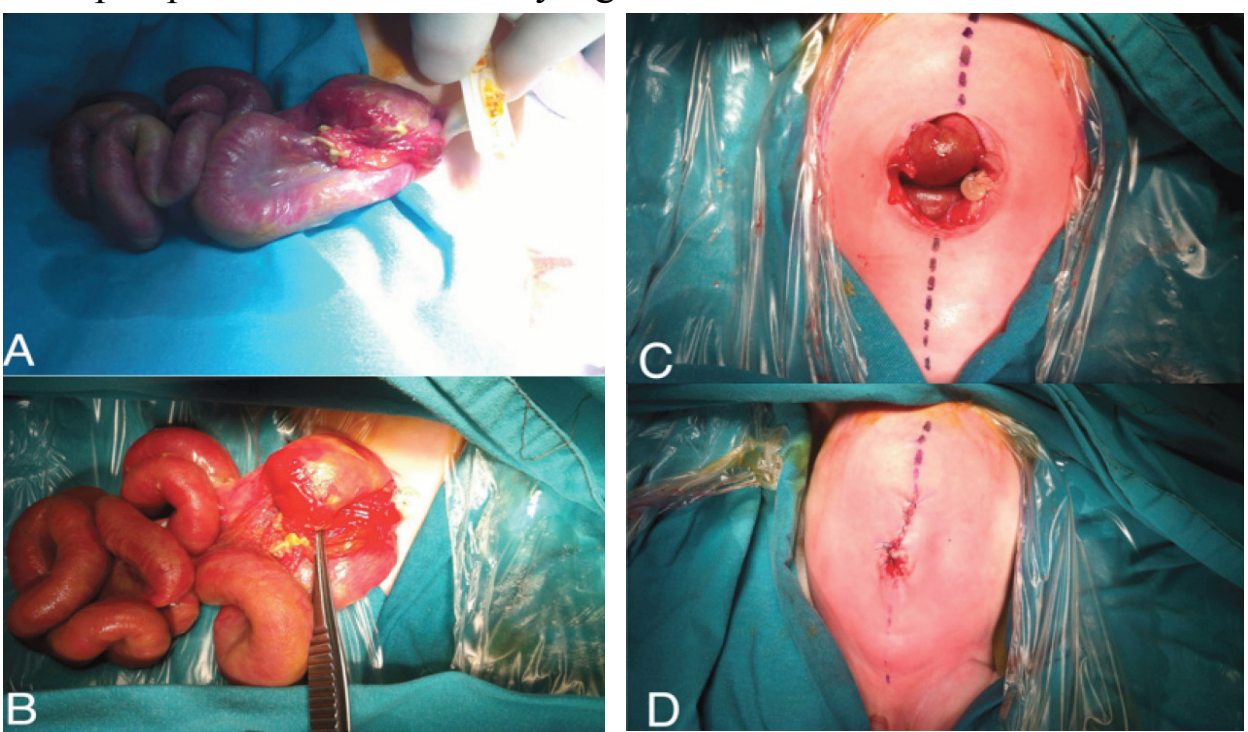

Gambar 6. (a) Gambaran pre operasi. (b) Eksplorasi eviserasi usus melalui defek paraumbilical kanan. (c) Menempatkan usus ke dalam abdomen. (d) Gambaran post operasi penutupan primer. ${ }^{24}$
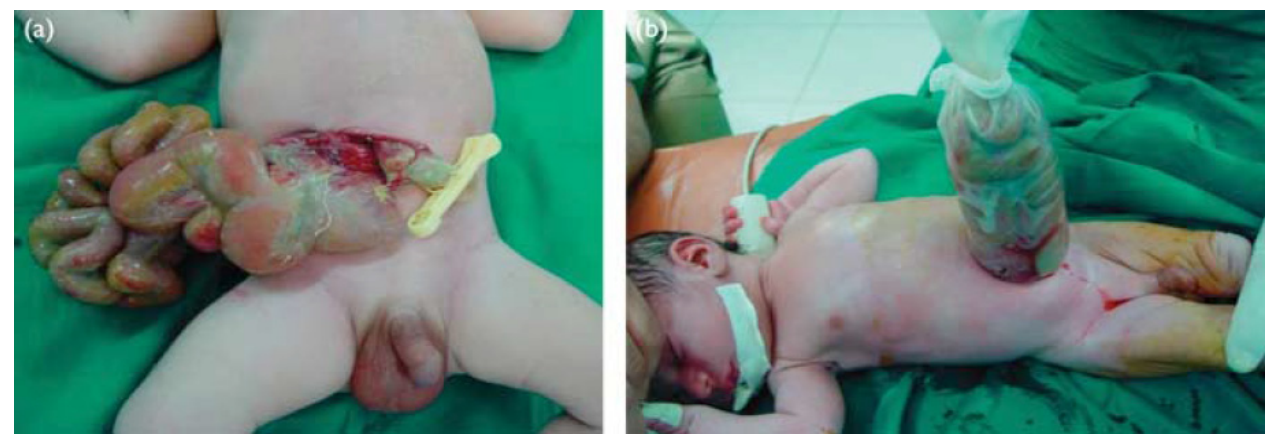

Gambar 7 (a) Gastroskisis: foreshortened dengan edema pada usus. (b) reduksi bertahap menggunakan spring-loaded silo. ${ }^{6}$ 

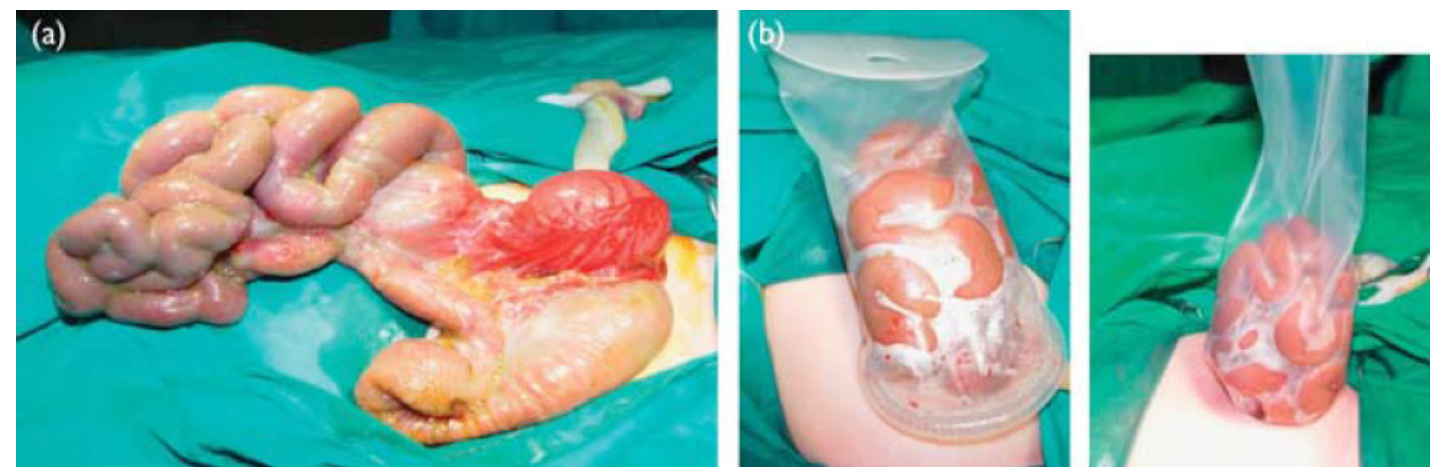

Gambar 8 (a) Gastroskisis tanpa komplikasi. (b) Reduksi bertahap menggunakan spring-loaded silo. ${ }^{6}$
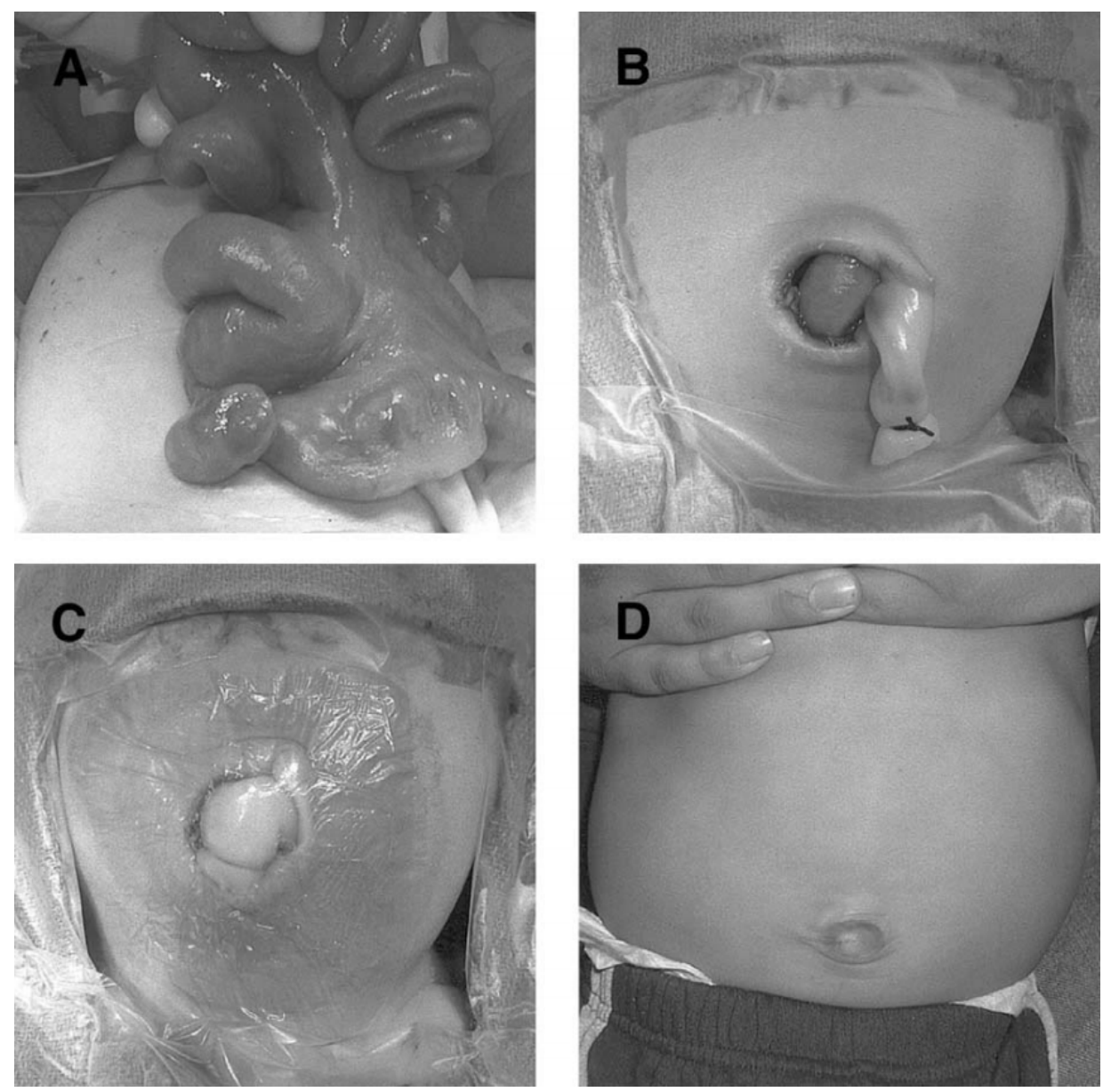

Gambar 9 Penutupan defek abdominal Gastroskisis menggunakan teknik penutupan tanpa jahitan. (a) Gastroskisis usus sebelum reduksi (b) Defek setelah reduksi usus. (c) Tali pusat disesuaikan untuk mengisi defek yang ditutupi dengan Tegaderm. (d) Anak yang sama pada saat berusia 18 bulan. ${ }^{24}$ 
Pemberian nutrisi enteral ditunda beberapa minggu sampai motilitas usus kembali normal. Perkiraan untuk memulai nutrisi enteral setelah penutupan bersifat subjektif, dan 1 penelitian menjelaskan bahwa hasil terbaik diamati ketika pemberian nutrisi enteral dimulai pada hari ke-7 paska operasi.

\section{Prognosis}

Perkiraan survival rate pada bayi dengan Gastroskisis berkisar antara 90\% hingga 95\%. Namun hal ini tergantung pada kompleksitas defek. Pasien dapat dikelompokkan berdasarkan risiko rendah (simple) atau risiko tinggi (complex). Gastroskisis kompleks adalah Gastroskisis yang disertai dengan satu atau lebih ciri-ciri berikut selama evaluasi: (1) atresia usus, (2) volvulus, (3) nekrosis, atau (4) perforasi. Kejadian Gastroskisis kompleks berkisar antara 10$15 \%$ dari semua kasus Gastroskisis. Sebuah meta-analisis yang dilakukan oleh Bergholz et al menjelaskan bahwa pasien dengan Gastroskisis kompleks memiliki risiko yang lebih tinggi untuk mengalami sepsis atau enterokolitis nekrotikans. Bayi baru lahir dengan Gastroskisis kompleks umumnya membutuhkan waktu yang lebih lama untuk mencapai pemberian nutrisi enteral. Durasi perawatan juga menjadi lebih lama. ${ }^{25}$

\section{Kesimpulan}

Peningkatan kasus Gastroskisis telah dicatat dalam beberapa dekade terakhir. Penatalaksanaan prenatal meliputi pemeriksaan ultrasonografi serial untuk memantau kehamilan akibat meningkatnya risiko restriksi pertumbuhan, kelainan cairan ketuban, dan kematian janin. Dilatasi usus intra-abdominal, polihidramnion, dan dilatasi lambung meningkatkan risiko terhadap komplikasi paska kelahiran. Metode persalinan dan waktu persalinan diperdebatkan dalam literatur ini. Kami merekomendasikan persalinan pada usia kehamilan 37 minggu dengan metode sectio caesarea. Manajemen neonatal meliputi persalinan di fasilitas kesehatan tersier dengan perawatan multidisiplin. Manajemen bedah paska kelahiran meliputi penutupan bedah primer, penutupan bertahap dengan silo, atau penutupan umbilikal tanpa jahitan.

\section{Daftar Pustaka}

1. Calderon RI, Montufar OG, Torres JS, Ceron LF. Gastroskisis. Case report and management in primary care services. Reportes de Caso. 2018;4(1):10-8.

2. Morazan AF, Andrade DS, Torres SJ, Zelaya WP, Izaguirre RE, Molina FA. Non-viable neonatal Gastroskisis: case report. iMedPub Journals. 2017;3(2):158.

3. Sudrajat I, Satoto H. Analisis kasus Gastroskisis. dalam makalah: Bagian/ SMF Anestesiologi FK Undip/RSUP dr.Kariadi Semarang. 2011.

4. Nukana RP, Darmajaya IM. Proporsi penggunaan teknik bedah dan mortalitas penyakit Gastroskisis di RSUP Sanglah pada tahun 2010-2012. dalam makalah: Bagian/SMF Bedah FK Unud/RSUP Sanglah Denpasar. 2012.

5. Ericki VS, Mert M, Ozdemir T, Koyluoglu G. Gastroskisis in a premature infant: a case report and review of literature. EC Paediatrics. 2018:400-5.

6. Hashish E, Amel A. Evolution of management of Gastroskisis. Annals of Pediatric Surgery. 2011;7(1):10-5.

7. Prefumo F, Izzi C. Fetal abdominal wall defects. Best Pract Res Clin Obstet Gynaecol. 2014 Apr;28(3):391-402

8. Stüber TN, Frieauff E, Weiß C, Zollner U, Wöckel A, Meyer T, Rehn M. Prenatal sonographic ultrasound predictors for the outcome in fetal Gastroskisis: a retrospective analysis. Arch Gynecol 
1. Obstet. 2016 May;293(5):1001-6.

2. Page R, Ferraro ZM, Moretti F, Fung KF. Gastroskisis: antenatal sonographic predictors of adverse neonatal outcome. Journal of pregnancy 2014(12):239406

3. Christison-Lagay ER, Kelleher CM, Langer JC. Neonatal abdominal wall defects. Semin Fetal Neonatal Med. 2011 Jun;16(3):164-72.

4. D'Antonio F, Virgone C, Rizzo G, et al. Prenatal risk factors and outcomes in Gastroskisis: a meta-analysis. Pediatrics. 2015; 136:e159-e169.

5. American College of Obstetricians and Gynecologists Committee on Genetics. Committee Opinion No. 581: the use of chromosomal microarray analysis in prenatal diagnosis. Obstet Gynecol. 2013;122:1374-1377.

6. Yilmaz J, Inanc I, Inan M. A case report: gastroscisis. TMSJ. 2016:22-25.

7. Nasr A, Langer JC, Canadian Paediatric Surgery Network. Influence of location of delivery on outcome in neonates with Gastroskisis. $J$ Pediatr Surg. 2012;47:2022-2025.

8. Mesas Burgos C, Svenningsson A, Vejde $\mathrm{JH}$, et al. Outcomes in infants with prenatally diagnosed Gastroskisis and planned preterm delivery. Pediatr Surg Int. 2015;31:1047-1053.

9. Baud D, Lausman A, Alfaraj MA, et al. Expectant management compared with elective delivery at 37 weeks for Gastroskisis. Obstet Gynecol. 2013;121:990-998.

10. Carnaghan H, Pereira S, James CP, et al. Is early delivery beneficial in Gastroskisis? $J$ Pediatr Surg. 2014;49:928-933 discussion 933.

11. Cain MA, Salemi JL, Paul Tanner $\mathrm{J}$, et al. Perinatal outcomes and hospital costs in Gastroskisis based on gestational age at delivery. Obstet Gynecol. 2014;124:543-550.
12. Youssef F, Laberge JM, Baird RJ, et al. The correlation between the time spent in utero and the severity of bowel matting in newborns with Gastroskisis. J Pediatr Surg. 2015;50:755-759.

13. Nasr A, Wayne C, Bass J, et al. Effect of delivery approach on outcomes in fetuses with Gastroskisis. J Pediatr Surg. 2013;48:2251-2255.

14. Al-Kaff A, MacDonald SC, Kent N, et al. Delivery planning for pregnancies with Gastroskisis: findings from a prospective national registry. Am J Obstet Gynecol. 2015;213:557.e1-557.e8.

15. Allin BSR, Tse WH, Marven S, et al. Challenges of improving the evidence base in smaller surgical specialties, as highlighted by a systematic review of Gastroskisis management. PLoS One. 2015; 10:e0116908.

16. Ross AR, Eaton S, Zani A, et al. The role of preformed silos in the management of infants with Gastroskisis: a systematic review and meta-analysis. Pediatr Surg Int. 2015;31:473-483.

17. Sandler A, Lawrence J, Meehan J, Phearman L, Soper R. A "plastic" sutureless abdominal wall closure in Gastroskisis. J Pediatr Surg. 2004 May;39(5):738-41.

18. Bergholz R, Boettcher M, Reinshagen K, et al. Complex Gastroskisis is a different entity to simple Gastroskisis affecting morbidity and mortality-a systematic review and metaanalysis. J Pediatr Surg. 2014;49:1527-1532. 